\title{
Shades of green and REDD: Local and global contestations over the value of forest versus plantation development on the Indonesian forest frontier
}

\author{
Michael Eilenberg \\ Department of anthropology, Aarhus University, Moesgaard Alle 20, DK-8270 Hojbjerg, Denmark. \\ Email: Michael@eilenberg.dk
}

\begin{abstract}
In a time of increasing land enclosures sparked by large-scale environmental initiatives and agricultural expansion, this paper examines local and global contestations over the value of forest on an Indonesian forest frontier. Engaging with recent debates on carbon forestry, the paper problematises the emerging initiatives of 'Reducing Emissions from Deforestation and Forest Degradation' known as REDD+ in the province of West Kalimantan, Indonesia. The paper argues that the general rush to implement REDD+ without intimate knowledge of the political landscape of resource struggle is in danger of generating new enclosures of land that may be easily appropriated by local elites, thus excluding less fortunate sections of local society. The paper shows how divergent interpretations of REDD+ are triggering land disputes, and how powerful actors readily appropriate REDD+ discourses as a tool to support divergent claims of land ownership. Government and villagers, through overlapping and contradictory engagements, negotiate REDD+ initiatives with global environmental actors and private plantation companies. The paper highlights the implications of these local realities for the successes of REDD+. The Kalimantan case highlights some of the dilemmas of carbon mitigation initiatives experienced in frontier regions throughout Southeast Asia, places that have become prime battlefronts of large-scale climate change initiatives and agrarian expansion.
\end{abstract}

Keywords: conservation, forest frontiers, Indonesia, land enclosures, oil palm, REDD+

\section{Introduction ${ }^{1}$}

In 2003, the head of the Kapuas Hulu district, located in a remote corner of the Indonesian province of West Kalimantan, announced the formation of the first 'Conservation District' in Indonesia. ${ }^{2}$ The main aim of this initiative was to attract national and international attention to the district's large forest conservation potential and cater to the rising global discourse on carbon trading and payment for environmental services like the emerging Reducing Emissions from Deforestation and forest Degradation (REDD+) initiative attempting to mitigate climate change. The concept of a Conservation District was further stimulated by a larger initiative sponsored by international donors and the World Wide Fund for Nature (WWF) in creating a transnational conservation corridor along the forested core of the island of Borneo under the name 'Heart of Borneo'. ${ }^{3}$ Paradoxically, however, the Conservation District was announced at the same time as the district was profiting immensely through engagements in widespread 'illegal' timber logging and negotiations with private agribusiness for opening up these same forestlands to large-scale oil palm plantations. As a district government official pragmatically confided to me during a fieldwork in 2011, 'Natural forest or (oil) palms, it's all green just different shades, why shouldn't we profit from both?'

The Kapuas Hulu case highlights some of the dilemmas and paradoxes of land struggle and resource access currently experienced in forested frontier regions throughout Southeast 
Asia, places that have become the prime battlefronts at a time of intensified large-scale agricultural enclosures and global focus on climate change, carbon trading and conservation. In these frontier regions, access to and exclusion from land have intensified immensely in the last decade as a consequence of the ongoing rush for 'free' land for agricultural expansion and nature conservation. As in the case of Kapuas Hulu, many frontier regions still contain large pockets of natural forest and are thus prime targets for international conservation efforts driven by the global climate discourse.

Taking into consideration the historical legacy of resource struggle and nature conservation on the Kapuas Hulu forest frontier, this paper further explores how these large-scale schemes and initiatives are transformed and translated into local settings with often unintended consequences. The outcomes of largescale climate initiatives like REDD+ as envisioned by international donor agencies and environmental NGOs often diverge from those envisioned by local governments and forestdependent villagers, creating misapprehensions. It is argued that when actors from different contexts (local, national and transnational institutions) engage in practical encounters, their discourses combine with local terms and practices, producing unexpected conjunctures or 'friction' (Tsing, 2005; Li, 2009). This line of enquiry investigates how global economic trends affect and change local landscapes and how frontier communities are shaped in national and global dialogues (Tsing, 2003; De Koninck, 2006; Akram-Lodhi and Kay, 2008; Geiger, 2008). Local sites are seen here as inserted into and constituted through market flows and networks that work on multiple scales. Global initiatives like REDD+ are inscribed into pre-existing landscapes of resource struggle, patronage, local politics and fuzzy land administration, and their ability to deliver equitable outcomes is very dependent on intimate understandings of these particular conjunctures.

The Kapuas Hulu district government, local elites and rural villages have a long and contested history of engagement with various powerful outsiders entering the region with the purpose of harvesting their forest resources or setting them aside for conservation purposes
(Wadley, 2002, 2003, 2005; Eilenberg, 2012a). A common feature within these engagements has been and still is that of exclusion from access to land and resources. These particular conjunctures have locally nurtured a flexible and pragmatic strategy in ensuring revenue flows and land claims among district government and villagers alike. This paper highlights the creative manner in which resource-rich districts like Kapuas Hulu in the last decade have simultaneously engaged with national development discourses promoting plantation development, transnational conservation schemes and global climate initiatives of carbon payments in order to secure steady revenue flows for district development. A basic argument is that local engagement with the many and overlapping schemes currently enacted in the Kapuas Hulu district is not so much about resistance to largescale enclosures in an attempt to maintain traditional subsistence living, but more about struggles of inclusion (and the terms of this inclusion) and making claims that will provide future economic security. Forest-dependent villagers in Kapuas Hulu are quite aware that powerful forces are entering the region, with or without local consent, and that exclusion from access to land and resources and elite capture is highly likely, as experienced so many times in the recent past.

The paper argues that in order to accommodate these powerful forces, local strategies include overlapping and often contradictory engagements with these large-scale schemes and initiatives. In the case of REDD+, the promise of future payment from standing forest stocks is invigorating local debates about land ownership and the legitimacy of access to land, which result in intimate exclusions of the less fortunate. In a recent attempt to expand our understanding of the dilemmas of intensified land struggle in Southeast Asia, Hall, Hirsch and $\mathrm{Li}$ suggest that we look at the various ways people gain access to and are excluded from land, especially the power inherent in acts of exclusion (Hall et al., 2011). This approach suggests an understanding of what they refer to as 'exclusion's double edge', which follows the basic argument that exclusion is an inevitable feature in the struggle to gain access to land and secure tenure security. People will always assert their claims to access at the expense of others, 
even if those others might be fellow villagers or kin, i.e. 'intimate exclusions' (Hall et al., 2011: 4; Howson and Kindon, 2015 - this issue).

Further, the REDD+ discourse is often articulated differently (or even misunderstood) by the various stakeholders involved (e.g. government, NGOs and funding agencies) depending on their individual goals or agendas (see Pasgaard, 2015 - this issue). This milieu of uncertainty and misapprehension creates opportunities for divergent local interpretations, often used to support existing and new claims to land. Although REDD+ initiatives in Kapuas Hulu are still in the early stages of planning (as is the case all over Indonesia), the mere rumours of future carbon credits within an emerging 'green economy' and possible large-scale land enclosures readily trigger local land disputes. The implementation of REDD+ schemes is further complicated by conflicting land allocation policies and strong lobbying for conversion of forestlands allocated for REDD+ into oil palm plantation development.

The paper proceeds as follows. In the next section I will discuss recent critical scholarly engagements with the social and political implications of REDD+, arguing that such initiatives in the global South could have a potentially negative effect on the forest-dependent poor as a consequence of unclear tenure rights and fuzzy national forest allocation policies. I then introduce the regional context and provide an overview of the different and overlapping historical phases of resource exploitation and conservation efforts in the region. That is followed by an examination of the emergent REDD+ initiatives in the district of Kapuas Hulu and how these are understood and interpreted locally (see map Fig. 1). In the final section, I consider the flexible manner in which local elites and district government interpret, value and appropriate these carbon sequestration programmes and discuss their potential exclusionary effects before concluding with the implications of these local realities for the future success of REDD+ initiatives in the region.

\section{The social dynamics of REDD+}

Deforestation and degradation of forests in the tropics are depicted as a major source of emissions of $\mathrm{CO}_{2}$. It is estimated that between $12 \%$ and $20 \%$ of total world emissions of $\mathrm{CO}_{2}$ come from deforestation. REDD (Reducing Emissions from Deforestation and Forest Degradation) is seen as one of the tools that can help to ensure more effective forest conservation and reduce the proportion of $\mathrm{CO}_{2}$ emissions (Angelsen, 2008). The REDD programme was launched in 2009 by the United Nations and is part of the Copenhagen Accord (COP-15). Later, the REDD initiative was broadened and became REDD+, when conservation, sustainable management of forests and enhancement of forest carbon stocks were included in the framework.

It is widely believed that REDD+ funds will create economic incentives for developing countries to maintain and strengthen the management of their forests and thus help lower global emissions of $\mathrm{CO}_{2}$. Under this initiative, developing countries can refrain from deforestation and be credited for the amounts of $\mathrm{CO}_{2}$ that are left untouched. These credits can then be sold to industrialised countries that need to reduce emissions to meet their own targets. REDD+ promises a range of co-benefits not only for the involved states but also for forestdependent communities. Claims of co-benefit realisation have, however, been questioned by many scholars. One concern touches upon how a global-level mechanism may be put into play on the ground. Implementation approaches tend to be primarily technical in nature, thus depoliticising REDD+ and ignoring the local web of power relations in which it will need to be embedded, and which it will also certainly reshape. Critics argue, among other things, that REDD+ policies can be manipulated and threaten to generate land grabs, displacement, conflicts, corruption and impoverishment (Phelps et al., 2010; Sikor et al., 2010; BeymerFarris and Bassett, 2012; Brockhaus et al., 2012; Edwards et al., 2012). As indicated above, REDD+ seems riddled with conflicts of interest. These can make the initiative very difficult to regulate without a combined understanding of the various interests at stake, and the relationships of power in which they are embedded, not only on a global and national scale but also locally (Clarke, 2010; Leggett and Lovell, 2012).

Indonesia was one of the 26 countries to sign the Copenhagen Accord in December 2009. It has set targets of $26 \%$ domestic emission reductions by 2020 and $41 \%$ with international 


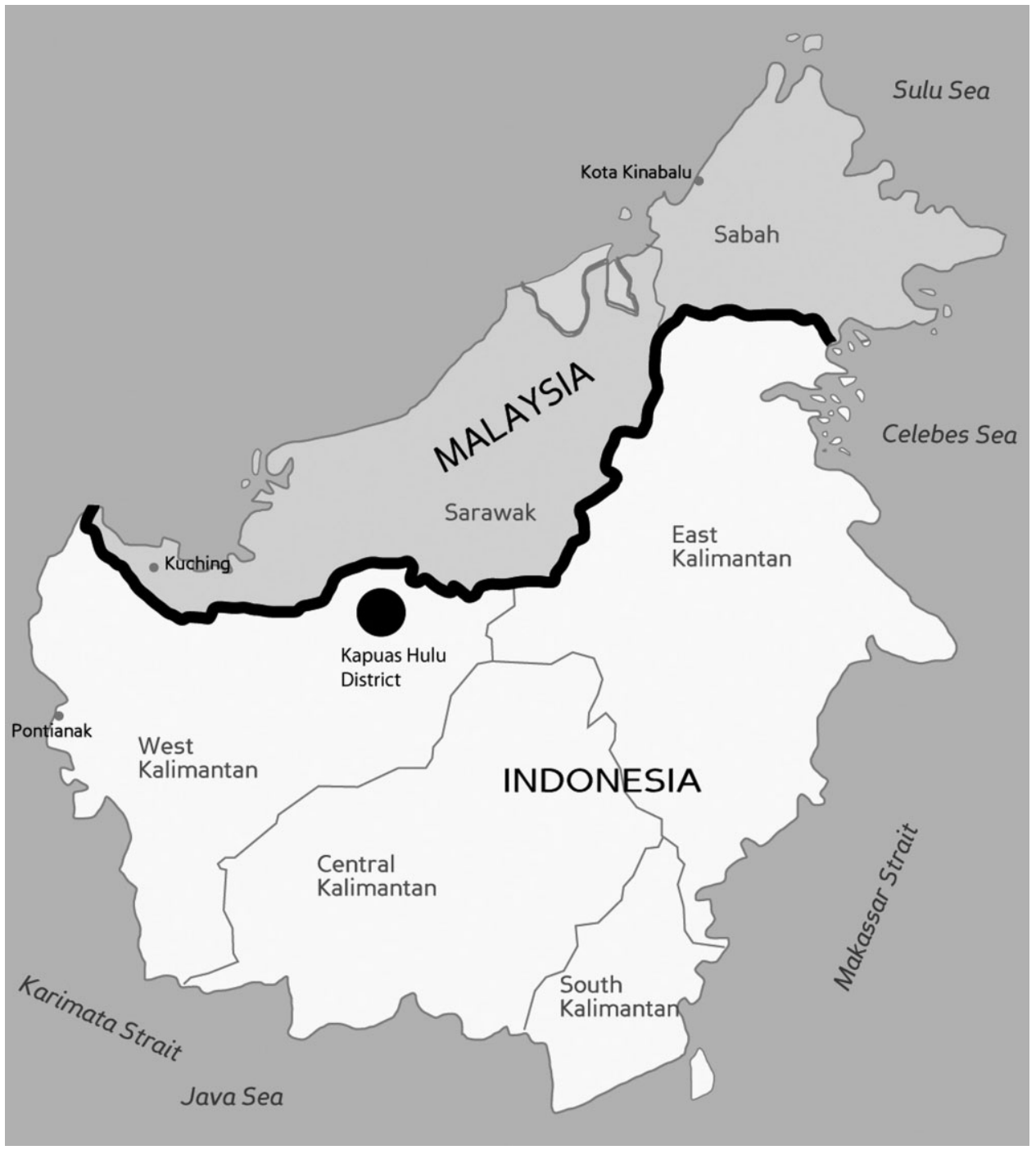

Figure 1. Map of Borneo

support (MoF, 2010). The largest contributions to achieving these goals are expected to come from the forest sector. Enticed by large bilateral and multilateral donor investments, the Indonesian government in 2009 officially confirmed its participation in the UN-REDD+ programme and multiple demonstration projects were initiated throughout the archipelago with support from international NGOs, bilateral donors (MoF, 2009) and the private sector (see Dixon and Challies, 2015 - this issue). In 2012, Indonesia had close to 40 REDD+ demonstration projects, a number that will probably grow in the years to come (Sekala Forest Climate Center, 2012).
Already from the outset of Indonesia's participation in the REDD+ scheme, critical voices were raised expressing worries that REDD+ initiatives could potentially deprive Indonesia's forest-dependent communities of access to customary forestlands and that more powerful players would capture the stream of benefits of future carbon offsets (Wright, 2011). Others argue that REDD+ could become a driver for large-scale land enclosures and dispossession of forest-dependent communities justified through the discourse of climate change - a mechanism that some have labelled 'green grabbing', or the appropriation of land and resources for environmental ends (Fairhead et al., 2012; McCarthy 
et al., 2012). However, one of the main concerns centres on the issue of insecure land tenure, which is a recurrent theme in Indonesia where legal rights to land and forest are precarious due to unclear and conflicting policies (Sikor et al., 2010; Larson, 2011; Lyster, 2011). Large tracts of forestlands (kawasan hutan) are formally under the authority of the Indonesian Ministry of Forestry and belong to the state. However, state authority over forest has continuously waxed and waned over time and is highly contested among the various levels of government, communities and private business interests.

Local land tenure in Kapuas Hulu is primarily based on customary rights or adat, and few villagers hold official land documents. In principle, all land/forest held under customary rights is de jure state land. While the Basic Forestry Law (No. 41/1999) released in 1999 recognises (in principle) the existence of local rights to what is considered customary forest, the legal standing of these rights is still very unclear and largely up to government interpretations as there are no clarifications of the term. Furthermore, until recently the Ministry of Forestry was the sole authority recognising claims to customary forest. However, in May 2013, Indonesia's Constitutional Court made a landmark ruling removing the authority over customary forest from the powerful Ministry of Forestry, announcing that customary forest may no longer be considered state forest land (kawasan hutan negara), but should be managed by the indigenous population. ${ }^{4}$ What this most recent court ruling entails for Indonesia's emerging REDD+ schemes and conflicts over forestlands, it is too early to predict, as the ruling still needs to be implemented on the ground and there are already indications that the ministry may be reluctant to relinquish its control over customary forest lands (Down to Earth, 2013).

Critics of REDD+ argue that this shifting legal uncertainty should be solved before the implementation of REDD+ schemes, while proponents assume that the question of insecure land tenure will be solved automatically through institutional and governance reforms triggered alongside the implementation of the REDD+ projects (Cotula and Mayers, 2009; Lyster, 2011; Larson et al., 2013). While most REDD+ pro- jects readily mention issues of tenure within project frameworks, no detailed strategy is included. However, looking back at the long and contested history of forest access and control in the district of Kapuas Hulu and elsewhere in Indonesia, the last assumption is a great delusion underestimating the complexity of land tenure arrangements (Clarke, 2010; Larson, 2011). Another and more regional critique focuses on the Indonesian government's inconsistencies and lack of commitment in regard to REDD+ (Brockhaus et al., 2012; Indrarto et al., 2012; Mahanty and McDermott, 2013). This critique was, among other things, triggered by the release of several new government regulations and decrees. These stimulated not only the expansion of oil palm plantations and mining concessions in regions that were targeted as potential REDD+ sites, ${ }^{5}$ but also the flawed attempt to prevent further forest conversion by issuing a two-year forest moratorium in 2011. The moratorium was later proved to be full of loopholes to be taken advantage of by the plantation and timber industry. Despite the ban on new licences, government officials continued to grant licences to mining and logging companies (Jakarta Globe, 2011; Murdiyarso et al., 2011). In May 2013, the Indonesian president extended the forest moratorium by another two years (Austin et al., 2014).

\section{The Kapuas Hulu frontier}

The district of Kapuas Hulu is situated at the distant head of the great Kapuas River $(1086 \mathrm{~km})$ in the most northern corner of the Indonesian province of West Kalimantan. The district covers $29842 \mathrm{~km}^{2}$ (20.33\% of the province) divided into no fewer than 23 subdistricts, 208 villages and 547 hamlets with a total population of 209860 or six persons per square kilometre (BPS-KB, 2010). The large majority of the district population earn their main income as small-scale rice farmers (swidden and paddy agriculture) and rubber cultivation supplemented by the collection of forest produce and circular labour migration to the main urban centres. More recently, new income opportunities have emerged in the rapidly expanding oil palm plantation industry.

Altogether, more than half of the district is classified as protected forest, thus falling under 
the authority of the state. As such, the frontier landscape is a patchwork of swiddens, forest gardens and old-growth forest criss-crossed by multiple logging roads and rivers. Until recently, the main economic sector in Kapaus Hulu has been forestry. Kapuas Hulu's economic dependency on forestry is more than twice as great as in other districts in the province (Yasmi et al., 2006). Due to its large forests, remote location and lack of functioning infrastructure, few other economic opportunities have been available. According to district statistics, an average of approximately $25282 \mathrm{~km}^{2}$ is said to belong to various categories of forest. That is more than $80 \%$ of the total land area (BPS-KB, 2010).

The history of resource exploitation on the Kapuas Hulu forest frontier is long and complex, with multiple actors, including timber and plantation companies, environmental NGOs and bilateral donor agencies entering the scene. During the so-called New Order Regime (1966-1998) of President Suharto, the widespread forest areas in the district were divided into large timber concessions and put in the hands of a small number of Indonesian companies, both state and privately owned. These concessions were given to members of the ruling elite in Jakarta and the Indonesian military as part of Suharto's rule of patronage (Eilenberg, 2012b). During this period of resource extraction, most of the revenue from timber flowed towards Jakarta while the district benefited little. After Suharto's fall and the onset of the Indonesian economic crisis in 1998, the new reform governments cancelled all timber concessions formerly run by Suharto's cronies. The transfer of authority over the forestry sector from the centre to the districts stipulated by the large-scale decentralisation process initiated by the new reform governments after 1999 quickly changed the dynamics of resource exploitation in Kapuas Hulu (Wadley and Eilenberg, 2005).

The decentralisation laws, among other things, stipulated that the districts should gain a larger share of benefits from the forestry sector. However, the new legislation was often inconsistent with already existing laws, and therefore created a great deal of confusion and ambiguity in relation to the right to control forest resources. The Kapuas Hulu district interpreted these laws as a go-ahead to take full control of the forestry sector, and although the legal status of timber extraction during this transition period was still undecided, the district governments invited private timber companies to come and cut their forest in return for royalties and taxes to district government (Eilenberg, 2012b). This timber boom greatly affected the local economy, and villagers experienced a steady flow of cash from timber harvested in their forestlands, although the larger share of revenues ended up in the pockets of district elites.

Under the presidency of Megawati Soekarnopoetri (2001-2004), the central government had begun to show a resistance towards the decentralisation process, especially the extent of autonomy gained by the districts over the management of local natural resources. Consequently, in 2002, the central government issued new government regulations (effective from 2003) that revoked the capacity of districts to issue logging permits, and thereby the centre attempted to reassert its authority over forest. ${ }^{6}$ The formal argument was that district governments were mismanaging the nation's forest resources, leading to an increase in illegal logging and corruption (Perdu, 2002). However, the district head (bupati) of Kapuas Hulu largely ignored this new regulation, as he claimed it was in conflict with the laws of regional autonomy and would lead to more than 34000 people losing their employment (Pontianak Post, 2003). In defiance of this attempt from central government to recentralise forest authority, the bupati further withheld the share of timber taxes that he was supposed to pay to the central government. During the logging boom, the Provincial Forestry Agency accused the bupati of withholding Forest Resource Provision funds (Provisi Sumber Daya Hutan, PSDH) and Reforestation Funds (Dana Reboisasi, DR) amounting to Rp 150 billion (US\$17 million). District courts have not yet found enough convincing evidence of these allegations to push the issue further, despite charges filed by the provincial prosecutor's office back in 2004 . $^{7}$

This period of fuzzy regional autonomy and booming timber industries ended abruptly in 2005, when the central government initiated several large-scale raids in the district (Wadley and Eilenberg, 2005). The 2005 presidential decree directed at eradicating illegal logging mentioned previously put much emphasis on 
what should be considered illegal timber extraction, but it presented no clear indication of what then was to be considered legal (Inpres, 2005). There was no clear boundary between legal and illegal, which meant that these new laws were just as fuzzy and open to the same degree of interpretation as the previous laws on Regional Autonomy that had inspired the districts to secure revenue from local natural resources in the first place. As elsewhere in the country, since 2005 the central government has gradually withdrawn the district's authority over forest management. The central government's timber stoppage severely affected the district economy, which had become largely dependent on the revenues from timber.

In the period from 2005 to 2007 , the district government, encouraged by central government, as an alternative to timber extraction began negotiating with private palm oil companies to open up the district for large-scale plantation development. In 2007, the district government issued no fewer than 21 plantation licences for the conversion of approximately 360000 hectares of land. District officials enthusiastically encouraged communities to engage in the plantation economy, claiming that large-scale oil palm cultivation would boost district revenue and improve local livelihood security, and promising that large-scale agrarian expansion was not incompatible with the district conservation efforts (Equator News, 2009). However, because of poor spatial planning and a lack of clear regulations, these plantation concessions often overlapped with locally claimed customary forestlands, triggering companycommunity conflicts (Yuliani et al., 2010; Kompas, 2011).

In addition, allegations were instantly made by local and international NGOs that plantation companies were breaking the law by encroaching into protected forest area, clearing forestland without proper environmental impact assessments (EIAs) and timber-cutting permits (Antara, 2008; Greenpeace, 2009; Colchester et al., 2014). As was the case during the period of the large-scale timber boom that ended in 2005, a small number of district and village elites acted as brokers between companies and communities, frequently using their authority as district officials or village heads to manipulate land allocation regulations and formal proce- dures of issuing plantation permits, while simultaneously negotiating private deals with plantation companies. The non-transparent and intricate process of gaining permits made it extremely difficult for local communities to appraise the legality of permits issued to companies within customary claimed forests (Colchester et al., 2014). Weak law enforcement led to communities laying complaints and encouraging acts of vigilantism against the oil palm companies. For example, in April 2012, a large group of customary Dayak ${ }^{8}$ leaders and villagers from five subdistricts on the Kapuas Hulu forest frontier demonstrated in full ritual regalia in front of the district office in Putussibau, demanding that the district government stop issuing plantation licences on locally claimed customary land and revoke already issued licences that overlapped with local claims. The Dayak leaders displayed their grievances on several large banners with the headlines, 'If oil palm plantations enters our land the people is ready for war', here referring to past acts of vigilantism against timber companies entering the area without local consent (Equator News, 2012).

Running parallel to and overlapping with the above processes were several large national and international attempts to promote conservation efforts in the forest-rich district. In the early 1990s, the Ministry of Forestry and the WWF, for example, promoted the development of a national park in the northern part of the district, which in 1995 resulted in the creation of the Betung Kerihun National Park (BKNP). The BKNP comprised no less than 800000 ha of old-growth hill forest along the border with Malaysia. From the very outset of its creation, the BKNP was highly contested as the 800000 ha of forestland was seen as part of local customary forest under the authority of local villages, and issues of local compensation remain unresolved today. Communities felt excluded from decision-making and saw few local benefits from the national park, as all resource exploitation within the park is illegal and few local jobs are generated. Initial promises of including local communities were largely broken and no economic development initiated, which resulted in distrust of the environmental NGOs and national park authorities. The BKNP later became part of the 
'Heart of Borneo' initiative. Five years later, in 1999, another large piece of forestland nearby, approximately 80000 ha of shallow lakes and swamp forest, was gazetted as a national park and named Danum Sentarum National Park (DSNP). This national park project (locally claimed as customary forest land) also created intense local conflicts over boundary disputes, resource access and fears of resettlement (Harwell, 2010). In general, top-down conservation efforts of the past within the district have created a large amount of distrust and discontent towards international conservation NGOs and crippled any genuine commitment towards large-scale conservation efforts among local communities. ${ }^{9}$ It was within this tradition of dispossession and exclusion that the REDD+ initiatives were first interpreted when introduced in the district.

\section{Rumours of REDD+}

In 2008-2009, the Kapuas Hulu district was selected as a REDD+ demonstration site by three international institutions/organisations: the German government-funded (Forest and Climate Change programme) FORCLIME; Fauna and Flora International (FFI); and the WWF. Initially, the lucrative carbon market promised within the REDD+ mechanism was seen among district officials as a new potential source of economic growth for the remote and underdeveloped district.

The FORCLIME initiative is part of a GermanIndonesian government partnership preparing Indonesia for a future REDD+ mechanism and mostly focusing on capacity building and technical assistance within the District Forestry Department with only sporadic visits to forestdependent communities. Their main aim is to prepare the district for a future carbon trading market and train local staff in monitoring carbon emissions, with special focus on community forestry (FORCLIME, 2013). The second organisation, $\mathrm{FFI}$, is initiating a businessoriented REDD+ pilot project for future carbon markets that is financially supported by the Australian Macquarie Bank in the Danau Siawan wetland and peat swamp forest (approx. 39000 ha). The area is under significant pressure for clearance and conversion to oil palm, illegal-logging activities and subsistence agri- culture clearance. One of the FFI's main objectives is to secure economic benefits for local communities to protect high-conservation-value forest and encourage the private sector and community to strengthen biodiversity conservation (FFI, 2008; Universitas Indonesia, 2012). Lastly, in relation to its Heart of Borneo initiative and the creation of a 'green corridor' between the two major national parks in the district (the BKNP and DSNP), the WWF have developed a REDD+ component that is to measure the amount of carbon sequestration in the project location (WWF West Kalimantan, 2011). All three of the above institutions are to a certain degree working together through joint workshops and data sharing.

As in past conservation projects, from the very outset of the REDD+ demonstration activities in Kapuas Hulu the discourse was primarily communicated within elite networks at district level and only sporadic information reached the community level; however, distorted rumours of this new phenomenon spread, and as with past 'development' initiatives REDD+ was quickly seen as another elite project like the initial promotion of the 'Conservation District' in 2003. District officials only communicated project objectives and benefits within intimate local political networks, leaving the large majority of villagers out of the decision-making process. A general sense of being excluded from information aroused villagers' resentment of the elite capture of conservation funding and the inequitable benefit-sharing in the past. Thus, most villagers saw little incentive in actively seeking information about the schemes. In everyday conversation, REDD+ was quickly reduced to the issue of the future disbursement of funds coming (among a small group of elite members of society) from rich countries while the issue of deforestation and forest protection was reduced to a mere footnote. Concerns focused primarily on how to split the benefits from future carbon credits at district and provincial levels.

Besides the economic aspects, REDD+ was also quickly linked to past conservation enclosures like the creation of national parks and the subsequent restriction of access to customary forest resources. As with past conservation projects, attempts to initiate community consent and participation in regard to REDD+ initiatives were first made after the start-up of the demon- 
stration project, which resembled previous topdown conservation efforts. In the first few years of REDD+ entering the district, very few people knew about its existence. Interviews with district government officials and NGO stakeholders reveal that information was initially withheld from the broader community because of the complexity of the REDD+ mechanism, unclear national REDD+ regulations, and not least because of the general REDD+ illiteracy among project developers themselves. As expressed by a local environmental NGO worker in 2012:

We are very cautious about disseminating general information about REDD+ because we ourselves are not fully aware of its scope and consequences; we are still trying to build up trust and understanding about the importance of conservation efforts within communities. Communities are very suspicious in regard to conservation because of past conflicts. We don't want to make promises about economic benefits in the shape of carbon credit payments because we don't know if REDD+ is a permanent initiative - we still need to be able to continue work in the district in a post-REDD+ era.

This pragmatic stand on REDD+ was widespread among the NGO workers interviewed, and understandable, taking past failures of benefit sharing within conservation efforts into consideration. Most forest-dependent communities had vivid experiences with conservation schemes entering the region only to disappear when donor funding ended, which over time have nurtured a pragmatic and sceptical attitude towards community involvement in conservation schemes. The NGO workers that had a long-term presence in the district were acutely aware of the importance of quickly delivering concrete outcomes for local communities and downplaying the conservation part of their projects. For example, as part of their REDD+ preparation activities, local WWF staff in Kapuas Hulu began creating rubber and gaharu nurseries to encourage alternative income opportunities. Rubber planting could then become a potential buffer against the environmentally destructive oil palm expansion pushing onto the boundaries of possible REDD+ sites. Instead of spending energy on socialisa- tion meetings explaining the complex world of climate change and carbon credits, local WWF staff opted for community-empowering projects like rubber planting and thus downplayed the 'conservation' part of their REDD+ preparations. This strategy was also a consequence of the rather strained relationship history between the WWF and many local forest-dependent communities. The WWF, for example, was involved in the initial development of BKNP, which is still highly contested locally. In 2005, the WWF was further involved in a large logging ban in the region, which angered many communities who had been economically dependent on the timber trade. Many saw the ban as unnecessary outside interference in local autonomy and the traditional management of customary forests (hutan adat) (Eilenberg, 2012b).

In contrast to the WWF, FFI, through their REDD+ initiative in the Danau Siawan area, introduced a much more hands-on and direct strategy by promising future income opportunities through carbon credits and financial compensation from REDD+ activities involving customary forest. However, a study of local perceptions of REDD+ carried out by researchers from the University of Indonesia among the involved communities in the Danau Siawan indicates that there was immense local confusion in regard to what REDD+ actually encompasses, and not least the mechanisms of carbon trading (Universitas Indonesia, 2012). The study shows that continuous emphasis on compensation and credits made a large percentage of people interviewed regard REDD+ as yet another resource extraction scheme, which again triggers concerns and fears based on past experiences in regard to loss of customary forest access. For example, during the previous periods of top-down timber extraction, timber companies made sweeping promises of compensation for local loss of customary forest that never materialised, thus fears and rumours circulated that the REDD+ pilot schemes were just a cover-up for timber companies to enter the region and yet again take control of the forest. The REDD+ initiatives were continuously interpreted and appropriated locally based on past experiences of resource struggle, exclusion and dispossession in the district. Further, the general confusion in regard to the technical function of 
the carbon trade and REDD+ in general encouraged rumours of dispossession from land and resources.

REDD+ was seen by some of the more cynical villagers as yet another attempt by central government to take control over customary forest by recentralising forest management. Within this debate, REDD+ was ultimately linked to issues of land rights and land tenure in general. Most forest-dependent communities in the district have no legally binding rights to their forestlands or formal land documents, and thus largely rely on traditional adat laws in managing access to land and forest. Such unclear tenure arrangements will of course affect the future allocation of REDD+ compensation or benefit sharing. However, the more resource-rich and well-connected village elites with upward networks within district and provincial government are increasingly positioning themselves by securing landownership by buying up community land from fellow villagers.

In 2011, for example, the author witnessed several cases of village heads that had issued land tenure letters, so-called Surat Keterangan Tanah (SKTs), to individual pieces of land that locally were considered common forestland. These SKTs were later used to obtain proper land certificates in order to sell off the land to, for example, plantation investors. However, not only at village level but also at district level, land documents and licences are manipulated. The immense outside interest in land investments and future economic gains has encouraged district officials in tandem with plantation companies to abuse their authority for economic gain by manipulating traditional adat systems or issuing land=use licences overlapping with customary forest. A large majority of these reported violations are not prosecuted and the companies continue their land conversion and cutting down of forest with impunity (Yuliani et al., 2010).

\section{Forest conservation vs. plantation development}

In Kapuas Hulu, like the rest of Indonesia, oil palm plantations have become an important driver of deforestation and thus play a crucial role in the REDD+ debate in the district. Oil palm plantations are rapidly expanding into forest areas that have been targeted for future REDD+ sites or push up against the buffer zones of already initiated pilot projects. The Kapuas Hulu district government is constantly measuring the potential benefits of future carbon credits versus instant economic gains from plantation or mining development. Past experiences have taught district government that international conservation initiatives wax and wane according to donor funding. They are difficult to work with and are often short-lived and thus not a viable income generator. The commitment and motivation towards conservation effort are thus less pronounced among district government representatives. Often, the weight tips towards activities like plantation development that provide instant benefits in the form of improved infrastructure and tax income. In 2007 alone, the district issued plantation permits to around 21 oil palm companies surrounding the DSNP and REDD+ pilot sites, and the number of licences has risen dramatically since. Several of these companies were subsidiaries $^{10}$ of the Sinar Mas Group, Indonesia's largest palm oil producer (Yuliani et al., 2010; Eilenberg, 2014). As sarcastically stated by a local NGO worker interviewed in 2012: 'If land conversion for oil palm continues at this speed there will be only palm trees left to mitigate carbon emissions'.

This trend is not only applicable for the Kapuas Hulu case, but generally for the rest of Indonesia's economically underdeveloped forest frontiers. If profitability is greater in the conversion of forest to oil palm than in preserving the forest for a REDD+ project, REDD+ will not be able to compete. Oil palm agriculture and other similar activities are economically attractive opportunities for the use of forestland; REDD+ will thus not be able to meet its primary goal - to avoid deforestation (Butler et al., 2009; Koh and Butler, 2010; Terauchi et al., 2014). As pragmatically declared by Hadi Daryanto, secretary-general of the Ministry of Forestry, to the British newspaper The Observer in 2010:

There is $\$ 10$ billion coming in from palm oil, $\$ 4$ billion from pulp and paper, and the people who work in these concessions are many, so we cannot just stop it all or the IMF will collapse us as an economy. So please be wise about this, who will pay for that? Europe and the US have a financial crisis and who is going 
to help us just for the sake of climate change? Nobody. We were told to democratize and this is the price of democracy. Climate change is the price of democracy. Indonesia is trying to be a good boy, but we can't paint the sky for you (McVeigh, 2010).

The ambiguity in Indonesia and globally over the legal definition of 'forest' has further encouraged a debate, not least among powerful members of the forestry and plantation sector in Indonesia, over whether plantations should be reclassified as forests and whether large-scale plantation operations such as oil palm operations could also mitigate climate change through the uptake of $\mathrm{CO}_{2}$ by the palms. Intense lobbying from the plantation industry has pushed decision-makers to consider whether palm oil growers should be able to save $\mathrm{CO}_{2}$ credits and participate in REDD+. The definition of 'forest' from the 'United Nations Framework Convention on Climate Change' is very broad, and natural forests and plantations, for example, are not differentiated (Sasaki and Putz, 2009). There have even been proposals to convert forest to oil palm plantations, both to retain $\mathrm{CO}_{2}$ and build an export industry. For example, in 2010, Wandojo Siswanto, a special adviser to the forestry minister, was quoted as saying the following: 'I think it would be good if we just say that palm oil plantations could also mitigate climate change through carbon sequestration through the nature of the trees' (Creagh, 2010). Comments like this do not align well with the initial idea behind REDD+, i.e. to prevent forest degradation and deforestation through carbon mitigation as oil palms store significantly less carbon than natural forest, but the plantations themselves and the peatland where they are often grown release large amounts of carbon when drained and burned to provide space for new oil palm seedlings. As in the case of Kapuas Hulu (Colchester et al., 2014), much palm oil in Indonesia is cultivated on drained peatlands, and peat areas store significant amounts of carbon (Carlson et al., 2013). ${ }^{11}$ Organic carbon, which is normally submerged, is suddenly unprotected from the air, where it decomposes and emits carbon dioxide.

Revenue generated by the governmentsponsored palm oil industry is much more than the $\$ 1$ billion offered by Norway to establish REDD+ in the country. ${ }^{12}$ The economic viability of REDD+ schemes thus, to a large degree, depends on the profitability of alternative land uses (Butler et al., 2009). ${ }^{13}$ As explained by a Kapuas Hulu village leader in a 2012 interview:

REDD+ does not provide transparent and immediate compensation to the community, unlike oil palm plantations that provide direct cash compensation and infrastructure like roads and electricity. It is very clear oil palm is much more beneficial for the community.

\section{Conclusions}

The insights gained from the Kapuas Hulu case show how histories of resource exploitation and contested conservation efforts are influencing local engagement with the REDD+ initiatives attempted or implemented in the district. It highlights how global initiatives like REDD+ often produce unintended effects as they are translated, transformed and contested through local social and economic processes.

Since the promotion of the 'Conservation District' in 2003, no genuine conservation efforts have been developed in the Kapuas Hulu district and the REDD+ pilot schemes have not yet produced any concrete financial benefits for local communities. Instead, the Kapuas Hulu forest frontier is becoming a fiercely contested battleground between large-scale plantation companies backed by powerful agribusiness interests and international environmental organisations backed by REDD+ schemes, with villagers and local elites, caught in between, negotiating their own rewards through flexible collaborations with both parties.

The paper has shown how these emerging enclosures of land and forest have increased local struggles over access to land and so far only benefited certain elite segments of local society, enhancing already entrenched local mistrust in outside-initiated conservation efforts. The Kapuas Hulu case reveals the contradiction at play in the overlapping agendas, competing interests and inconsistencies in district conservation policy, which have been nurtured through decades of resource exploitation and failed conservation schemes. The pragmatic strategy of 'betting on both horses' enacted by 
the district government in order to secure shortterm funding for district development plus the extensive pressure from plantation companies, conversion of forestlands and insecure tenure arrangements do not bode well for the future of REDD+ in the district. With the growing number of failed or failing REDD+ pilot projects throughout Indonesia and the global carbon market on the brink of collapse, REDD+ in its current form faces serious challenges. Forest areas targeted for REDD+ projects are under a constant threat of being cleared for oil palm plantations, which nationally and locally often are perceived as a more instant and profitable land use than possible future financial compensation for avoiding converting standing forests through REDD+.

Yet the discussions of tenure insecurity and land rights that the REDD+ discourse brings along might produce positive outcomes. Several NGOs working in the Kapuas Hulu district have realised that the initial focus on carbon credits and climate mitigation within REDD+ is less viable and are consequently prioritising their resources towards empowering communities in regard to issues of tenure rights and supporting small-scale income-generating initiatives like rubber planting schemes. However, such initiatives make for an enormously difficult task as the powerful plantation economy and the large flows of revenue it generates are rapidly changing local forest landscapes and access to land and resources. Possible REDD+ sites are rapidly being converted into large-scale mono-crop plantations, leaving little room for alternative land uses.

\section{Notes}

1 Research for this paper was conducted during extended fieldwork in the district of Kapuas Hulu from 2002 to 2013, approx. 25 months. Interviews were carried out with a wide array of local and national actors ranging from state officials, politicians, NGOs and local elites (village heads and tribal heads) to local community members. Interviews were triangulated with data from government/NGO reports and newspaper clippings. Fieldwork in 2012 and 2013 was funded by a research grant from the Aarhus University Research Foundation under the AU-IDEAS research programme. The usual disclaimers apply.

2 Kapuas Hulu District Head Decree No. 144/2003.

3 The Heart of Borneo is a transboundary conservation initiative between Indonesia, Malaysia and Brunei ini- tiated in by the WWF in 2007 to protect approx. $220000 \mathrm{~km}^{2}$ of forest at the core of Borneo.

4 Constitutional Court Ruling 35/PUU-X/2012, 16th May 2013.

5 See, for example, the issuance of Law No. 4/2009 on Mineral and Coal Mining (Mining Law), which justified opening up production forest and protected areas for mining, and Ministry of Agriculture Regulation No.14/ 2009 on the guidelines on the use of peatlands for oil palm cultivation.

6 Just before leaving office in 2004, President Megawati replaced the 1999 decentralisation laws with yet another law (no. 32/2004) on regional autonomy. The law, among other things, reaffirms the status of provincial government and gives far-reaching authority to central government in controlling district government, such as supervision of various regulations, decisions or policies decided at the district level (Barr et al., 2006).

7 The late bupati allegedly did not deposit PSDH/DR fees in the Minister of Forestry's account, but directly transferred the fees to regional accounts and later to a personal account (Rinaldi et al., 2007).

8 Umbrella term for native ethnic groups of Kalimantan.

9 However, while large international NGOs have huge difficulty in gaining local respect, a few locally run environmental NGOs have been more successful, especially because of their long-term commitment in the district and high focus on local income-generating projects.

10 PT. Buana Tunas Sejahtera, PT. Sentra Karya Manunggal, PT. Khatuliustiwa Agra Abadi, PT. Kapuas Indo Palm Industri, PT. Sawit Kencana Kapuas and PT. Citra Nusa Indonesia. Each company has a 20 000-ha licence (interview with district official, July 2007).

11 The palm oil plantations controlled by the Sinar Mas Group in the Kapuas Hulu district have been accused of clearing forestland for plantations without proper permits and draining areas of deep peat (Greenpeace, 2008, 2009).

12 Indonesia is currently the world's largest producer of crude palm oil and this trade is expanding (FAS, 2013).

13 Studies indicate that future REDD+ payments, if successfully implemented, can be economically competitive in regard to alternative land uses like oil palm plantations (Hein and van der Meer, 2012).

\section{References}

Akram-Lodhi, A.H. and C. Kay (2008) Peasants and globalisation: Political economy, rural transformation and the agrarian question. London: Routledge.

Angelsen, A. (2008) Moving ahead with REDD: Issues, options and implications, Bogor, Indonesia: Center for International Forestry Research.

Antara (2008) WWF: Perluasan Sawit di Kapuas Hulu Rambah Hutan Lindung. Antara 10 May.

Austin, K., A. Alisjahbana, T. Darusman et al. (2014) Indonesia's forest moratorium: Impacts and next steps. Working Paper, Washington, DC: World Resources Institute.

Barr, C. I., A.P. Resosudarmo, A. Dermawan and J. McCarthy (2006) Decentralization of forest administra- 
tion in Indonesia: Implications for forest sustainability, economic development and community livelihoods. Bogor, Indonesia: Center for International Forestry Research.

Beymer-Farris, B.A. and T.J. Bassett (2012) The REDD menace: Resurgent protectionism in Tanzania's mangrove forests, Global Environmental Change 22(2): 332-341.

BPS-KB (2010) Propinsi Kalimantan Barat dalam angka, Pontianak: Badan Pusat Statistik, Propinsi Kalimantan Barat.

Brockhaus, M., K. Obidzinski, A. Dermawan, Y. Laumonier and C. Luttrell (2012) An overview of forest and land allocation policies in Indonesia: Is the current framework sufficient to meet the needs of REDD+?, Forest Policy and Economics 18(0): 30-37.

Butler, R.A., L.P. Koh and J. Ghazoul (2009) REDD in the red: Palm oil could undermine carbon payment schemes, Conservation Letters 2(2): 67-73.

Carlson, K.M., L.M. Curran, G.P. Asner, A.M. Pittman, S.N. Trigg and J.M. Adeney (2013) Carbon emissions from forest conversion by Kalimantan oil palm plantations, Nature Climate Change 3(3): 283-287.

Clarke, R.A. (2010) Moving the REDD debate from theory to practice: Lessons learned from the Ulu Masen Project, Law, Environment and Development Journal 6(1): $1-36$.

Colchester, M., N. Jiwan and E. Kleden (2014) Independent review of the social impacts of golden agri resources forest conservation policy in Kapuas Hulu District, West Kalimantan. Forest Peoples Programme and TUK Indonesia.

Cotula, L. and J. Mayers (2009) Tenure in REDD: Start point or afterthought?. London: International Institute for Environment and Development, IIED.

Creagh, S. (2010) Indonesia may let palm oil grovers collect $\mathrm{CO}_{2}$ credits. Reuters, 9 August.

De Koninck, R. (2006) On the geopolitics of land colonization: Order and disorder on the frontiers of Vietnam and Indonesia, Moussons 9(10): 33-59.

Dixon, R. and E. Challies (2015) Making REDD+ pay: Shifting rationales and tactics of private finance and the governance of avoided deforestation in Indonesia, Asia Pacific Viewpoint 56(1): 6-20.

Down to Earth (2013) A turning point for Indonesia's indigenous peoples. Down to Earth Update, 7 June.

Edwards, D.P., L.P. Koh and W.F. Laurance (2012) Indonesia's REDD+ pact: Saving imperilled forests or business as usual?, Biological Conservation 151(1): 41-44.

Eilenberg, M. (2012a) At the edges of states; Dynamics of state formation in the Indonesian borderlands. Leiden, The Netherlands: KITLV Press.

Eilenberg, M. (2012b) The confession of a timber baron: Patterns of patronage on the Indonesian-Malaysian border, Identities: Global Studies in Culture and Power 9(2): 149-167.

Eilenberg, M. (2014) Frontier constellations: Agrarian expansion and sovereignty on the IndonesianMalaysian border, The Journal of Peasant Studies 41(2): 157-182.

Equator News (2009) Perkebunan sawit dongkrak kesejahteraan masyarakat, Equator News, 12 May.
Equator News (2012) Masyarakat adat tolak perusahaan perkebunan, Equator News, 26 April.

Fairhead, J., M. Leach and I. Scoones (2012) Green grabbing: A new appropriation of nature?, The Journal of Peasant Studies 39(2): 237-261.

FAS (2013) Indonesia oilseeds and products annual report 2013. Washington, DC: United States Department of Agriculture, Foreign Agricultural Service.

FFI (2008) REDD demonstration project concept note: Reducing emissions from peat swamp forest conservation and degradation, Danau Sentarum Lakes plain peat swamp forest, Kapuas Hulu, West Kalimantan Province, Fauna Flora International.

FORCLIME (2013) Support for reduced emissions from deforestation and forest degradation (REDD), forests and climate change programme. Briefing Note 1. Jakarta.

Geiger, D. (2008) Frontier encounters: Indigenous communities and settlers in Asia and Latin America. Copenhagen, Denmark: IWGIA.

Greenpeace (2008) How Unilever palm oil suppliers are burning up Borneo. London: Greenpeace.

Greenpeace (2009) Illegal forest clearance and RSPO greenwash: Case studies of Sinar Mas. London: Greenpeace.

Hall, D., P. Hirsch and T.M. Li (2011) Powers of exclusion: Land dilemmas in Southeast Asia. Singapore: NUS Press.

Harwell, E.E. (2010) Fluid landscapes and contested boundaries in Danau Sentarum, Borneo Research Bulletin 41: 36-61.

Hein, L. and P.J. van der Meer (2012) REDD+ in the context of ecosystem management, Current Opinion in Environmental Sustainability 4(6): 604-611.

Howson, P. and A. Kindon (2015) Analysing access to the local REDD+ benefits of Sungai Lamandai, Central Kalimantan, Indonesia, Asia Pacific Viewpoint 56(1): 96-110.

Indrarto, G.B., P. Murharjanti, J. Khatarina et al. (2012) The context of REDD+ in Indonesia: Drivers, agents and institutions. CIFOR Working Paper, 92.

Inpres (2005) Pemberantasan penebangan kayu secara illegal di kawasan hutan dan peredarannya di seluruh wilayah Republik Indonesia. Instruksi Presiden Republik Indonesia, Inpres, No. 4, March 18.

Jakarta Globe (2011) Indonesia forest moratorium a 'bitter disappointment', Jakarta Globe, 20 May.

Koh, L.P. and R.A. Butler (2010) Can REDD make natural forests competitive with oil palm plantations?, International Tropical Timber Organization (ITTO) 19(1): 9-10.

Kompas (2011) Masyarakat adat tolak sawit, Kompas, 12 September.

Larson, A.M. (2011) Forest tenure reform in the age of climate change: Lessons for REDD+, Global Environmental Change 21(2): 540-549.

Larson, A.M., M. Brockhaus, W.D. Sunderlin et al. (2013) 'Land tenure and REDD+: The good, the bad and the ugly', Global Environmental Change 23(3): 678-689.

Leggett, M. and H. Lovell (2012) Community perceptions of REDD: A case study from Papua New Guinea, Climate Policy 12: 115-134. 
Li, T.M. (2009) Exit from agriculture: A step forward or a step backward for the rural poor?, The Journal of Peasant Studies 36(3): 629-636.

Lyster, R. (2011) REDD+, transparency, participation and resource rights: The role of law, Environmental Science Policy 14(2): 118-126.

McCarthy, J.F., J.A.C. Vel and S. Afiff (2012) Trajectories of land acquisition and enclosure: Development schemes, virtual land grabs, and green acquisitions in Indonesia's Outer Islands, The Journal of Peasant Studies 39(2): 521-549.

McVeigh, T. (2010) Borneo's majestic rainforest is being killed by the timber mafia, The Observer, 24 October.

Mahanty, S. and C.L. McDermott (2013) How does 'free, prior and informed consent' (FPIC) impact social equity? Lessons from mining and forestry and their implications for REDD+, Land Use Policy 35(0): 406416.

MoF (2009) National strategy on reducing emissions from deforestation and forest degradation in Indonesia, Readiness phase, draft. Jakarta, Indonesia: Ministry of Forestry (MoF).

MoF (2010) Indonesia second national communication under the United Nations Framework Convention on Climate Change (UNFCCC). Jakarta. Indonesia: Ministry of Forestry (MoF).

Murdiyarso, D., S. Dewi, D. Lawrence and F. Seymour (2011) Indonesia's forest moratorium: A stepping stone to better forest governance? A stepping stone to better forest governance? Bogor, Indonesia: Center for International Forestry Research.

Pasgaard, M. (2015) Lost in translation? How project actors shape REDD+ policy and outcomes in Cambodia, Asia Pacific Viewpoint 56(1): 111-127.

Perdu (2002) Tata hutan dan penyusunan rencana pengelolaan hutan, pemanfaatan hutan dan pengunaan kawasan hutan. Peraturan Pemerintah Republik Indonesia, No. 32.

Phelps, J., E.L. Webb and A. Agrawal (2010) Does REDD+ threaten to recentralize forest governance?, Science 328(5976): 312-313.

Pontianak Post (2003) Tambul : Tak berpihak ke rakyat kecil, SK HPH 100 Ha dicabut, 34 ribu pekerja nganggur, Pontianak Post, 4 October.

Rinaldi, T., M. Purnomo and D. Damayanti (2007) Fighting corruption in decentralized Indonesia. The local government coruption study (LGCS). The World Bank Office, Indonesia.

Sasaki, N. and F.E. Putz (2009) Critical need for new definitions of 'forest' and 'forest degradation' in global climate change agreements, Conservation Letters 2(5): 226-232.

Sekala Forest Climate Center (2012) Indonesia - REDD demonstration activities, from Website: http://forest climatecenter.org/files/2012-03\%20Indonesia\%20 REDD\%20Demonstration\%20Projects_105dpi.jpg
Sikor, T., J. Stahl, T. Enters et al. (2010) REDD-plus, forest people's rights and nested climate governance, Global Environmental Change 20(3): 423-425.

Terauchi, D., N. Imang, M. Nanang, M. Kawai, M.A. Sardjono, F. Pambudhi and M. Inoue (2014) Implications for designing a REDD+ program in a frontier of oil palm plantation development: Evidence in east Kalimantan, Indonesia, Open Journal of Forestry 4: 259-277.

Tsing, A.L. (2003) Natural resource and capitalist frontiers, Economic Political Weekly 38(48): 5100-5106.

Tsing, A.L. (2005) Friction: An ethnography of global connection, Princeton, NJ: Princeton University Press.

Universitas Indonesia (2012) Final Report: Kajian Sosial dan Kelembagaan Terkait dengan Pengelolaan Hutan Dalam Skema REDD, Daerah Danau Siawan Belida, Kabupaten Kapuas Hulu, Provinsi Kalimantan Barat. Departemen Antropologi, Fakultas Ilmu Sosial dan Ilmu Politik, Universitas Indonesia, Depok.

Wadley, R.L. (2002) The history of displacement and forced settlement in West Kalimantan, Indonesia, in D. Chatty and M. Colchester (eds.), Conservation and indigenous mobile peoples: Displacement, forced settlement and sustainable development, pp. 313-328. Oxford: Berghahn Books.

Wadley, R.L. (2003) Lines in the forest: Internal territorialization and local accommodation in West Kalimantan, Indonesia (1865-1979), South East Asia Research 11(1): 91-112.

Wadley, R.L. (2005) Histories of the borneo environment. Verhandelingen van het koninklijk instituut voor taal-, land- en volkenkunde; 231. Leiden, The Netherlands: KITLV Press.

Wadley, R.L. and M. Eilenberg (2005) Autonomy, identity, and 'illegal' logging in the borderland of West Kalimantan, Indonesia, Asia Pacific Journal of Anthropology 6(1): 19-34.

Wright, G. (2011) Indigenous people and customary land ownership under domestic REDD+ frameworks: A case study of Indonesia, Law, Environment and Development Journal 7(2): 119-130.

WWF West Kalimantan (2011) Corridor restoration: Scenario for the restoration of the important biological corridor between Sentarum National Park and Betung kerihun National Park. Including estimation of carbon sequestration by projected growth of mixed plantations in Lanjak, West Kalimantan, Indonesia. West Kalimantan, Indonesia: World Wildlife Fund.

Yasmi, Y., G.Z. Anshari, H. Komarudin and S. Alqadri (2006) Stakeholder conflicts and forest decentralization policies in West Kalimantan: Their dynamics and implications for furture forest management, Forests, Trees and Livelihoods 16: 167-180.

Yuliani, E.L., Y. Indriatmoko, M.A. Salim et al. (2010) Biofuel policies and their impact on local people and biodiversity: A case study from Danau Sentarum, Borneo Research Bulletin 41: 109-144. 